\title{
Acts or events? A perspective from the marketing $\mathrm{mix}$
}

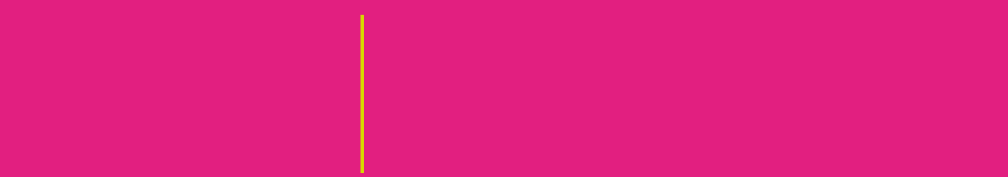

\author{
PhD. Marta Pulido Polo \\ University of Seville. Spain. \\ martapulido@us.es \\ https://orcid.org/0000-0001-5504-0438
}

DOI: http://dx.doi.org/10.12795/IROCAMM.2018.i1.04

\begin{abstract}
Resumen: La literatura existente en torno a las relaciones píublicas, el ceremonial y el protocolo alterna como sinónimos los términos actos y eventos. A través de una revisión teóricoconceptual, el principal objetivo de este trabajo es demostrar que ambos términos obedecen a realidades diferentes. Los resultados demuestran que, mientras que la organización de actos responde, desde la perspectiva de las relaciones públicas, a las necesidades comunicativas de las organizaciones; los eventos son herramientas que, desde la perspectiva del Mix de Marketing, permiten satisfacer las necesidades económicas, fundamentalmente, de las empresas.
\end{abstract}

Palabras clave: relaciones públicas, marketing, actos, eventos, protocolo.

Abstract: The existing public relations, ceremonial and protocol literature alternates the terms acts and events as synonyms. Through a theoretical-conceptual revision, the main objective of this work is to demonstrate that both terms obey different realities. The results show that, while the organization of acts responds, from the perspective of public relations, to the communicative needs of the organizations; Events are tools that, from the perspective of the Marketing Mix, allow meeting, mainly, the economic needs of companies.

Keywords: public relations, marketing, acts, 


\section{Introduction}

In the Spanish scientific reality of recent years, there seems to be a still incipient academic interest in the organization of acts and events. The continuous distinction that is established between both terms, acts and events, suggests a priori that there is an evident conceptual differentiation between both of them. However, as we will develop throughout this work, there are very few empirical works of rigor that are oriented towards the specific use of each of the terms. In fact, in most of the existing works on the topic under study, the words, act and event, are often used interchangeably, even using them as synonyms, a matter that incurs, in our point of view, serious inaccuracies and generalities that contribute to degrade its academic and conceptual value from the scientific point of view.

The question is that, although the organization of both acts and events arises from the practical development of public relations and, therefore, both concepts have been applied tactically to respond quickly to the communication needs of companies and institutions, and it must now proceed to carry out an adequate academic and disciplinary development capable of responding to the questions raised by the rapid natural evolution that acts and events have had as organizational management tools.

In this sense, the main objective of this work is to properly explain the specific features that, against the acts, turn to the events into a technique at the service of Marketing Mix, trying to propose a sustained model of commercial communication in the organization of commercial events, also called brand or product events.

Framed in this main objective, the successive development of the following secondary objectives is necessary:

- OS1: Define the concept of public relations through its differential characteristics

- OS2: Distinguish between managerial and marketinian currents of public relations.

- OS3: Perform a conceptual delimitation of the terms act and event.

- OS4: Determine the differential characteristics that are established between act and event

- OS5: Observe the organization of events as a tool of the Marketing Mix.

In order to approach these objectives is designed a methodology sustained in a theoretical revision based on the use of secondary sources. 


\section{Status of the question}

\subsection{The strategic concept of public relations}

From its strategic and managerial postulates, public relations should be conceived as a directive function oriented to manage in a planned way the relationships that are established between an organization and the public of its environment (Austin and Pinkleton, 2015; Wilcox, Cameron and Xifra, 2012, Xifra, 2003, Cutlip, Center \& Broom, 2001, Wilcox, Autt, Agee and Cameron, 2000, Grunig and Hunt, 2000) aimed at achieving appropriate levels of image and reputation and the convergence of organizational management to needs of their environment (Grunig, 2009: 8-10).

In this sense, public relations are responsible for generating and managing dialogical communication systems aimed at managing the interrelationships established between organizations, understood as social structures (Xifra, 2009), and their key audiences, understood as sectors or social groups. of the environment with which the organization maintains a system of mutual interference.

However, in recent times, one of the most current trends that has been used to define public relations is the relational perspective that, as advocated by Ledingham and Brunning (1998) and subsequently developed by Ledigham (2003 and 2011), translates the point of attention of the discipline from the concept of communication to that of relationship. In this process, communication techniques are used as an auxiliary and subsidiary element, but not fundamental or essential to relational theory and practice. Under this prism, and from this double theoretical-pragmatic functional dimension, the concept of public relations, can be deduced from the original AngloSaxon term public relations, alludes to the strategic management of the network of interrelationships necessarily established between an organization and your publics universe.

In any case, the strategic focus of public relations reveals a series of defining characteristics that identify public relations and differentiate them from other communication systems, such as the publicity communication system. These differences pivot essentially around two variables that are established as basic conditioning factors of the relational communication system: its bidirectional nature and its holistic and managerial nature. 


\subsubsection{Public relations as a bidirectional communication system}

Bidirectionality is the first and most obvious distinguishing feature of public relations. The bidirectionality (also called feedback) inherent in the relationship process is based on its ability to extract information from the environment, process it, and return to society a corporate behavior that responds to the demands and interests of the public organization map. That is, through public relations, organizations establish and manage effective mechanisms through which they can be permeable to the public's expectations of their corporate behavior, allowing a constant and fluid system, a dialogic system, organization- public of the environment (Pulido, 2016: 16-17).

\subsubsection{The holistic and managerial nature of public relations}

In its natural environment, public relations must be conceived from a holistic perspective, that is, it affects everything that is related to public perception (either between internal publics or external ones) of the organization that promotes them: from Personal attention to your activity in social networks. This means that, to understand the functionality of public relations, its role should be understood as the backbone of corporate behavior (understood in the broadest sense) of the company that applies them. And therefore, from this point of view, public relations can only be conceived from strategic approaches conceived from the direction of the organization, since its usefulness affects each and every one of the departments that make up the company (Pulido, 2016: 19- 20).

\subsubsection{The organization of ceremonial acts as a technique of corporate and institutional public relations}

From this perspective, academic work aimed at placing the organization of events as a tool for managing the relationships established between a corporation and institution and its publics (Otero, 2000, 2009, 2011 and 2017; Xifra 2007; 2011; Martínez, 2013; Pulido, 2012, 2015, 2016 and 2017). In general, these works defend the organization of events as a tool capable of effectively transferring certain messages of legitimacy, associated with the issuing entity, to the universe of publics of corporations and institutions.

In spite of this, it is important to note that some of these authors alternate the terms event and acts, using them as synonymous but always to refer to the same phenomenon: the management of the organizational communication. 


\subsection{Public relations from the instrumental perspective of marketing}

However, in addition to this holistic and managerial perspective, which is observed from the theory of communication, which highlights the strategic and structural nature of public relations, there is a whole Marketinian current that observes, works and studies public relations from a perspective integrated tactics in the $P$ for the promotion of the Marketing Mix (Armstrong and Kotler, 2016, Santesmases, 2013, Reinares and Paredes, 2003, Kitchen and Papasolomou, 1997).

The contributions of Kotler and Keller (2006: 629-630) lead this instrumental perspective of public relations, limiting its functionality to the promotion of the image of companies and their products. In this regard, they distinguish between two types of public relations that should be managed, from their perspective, from the marketing department: social public relations and commercial or marketing public relations that feed each other in pursuit of the economic objectives of the company through tasks such as influencing consumer groups, repositioning products, supporting the launch of products, etc.

Kotler, Keller, Brady et. al. (2009: 748) propose, in addition, that one of the essential characteristics of the so-called MPR (Marketing Public Relations) or public relations of Marketing, is its capacity to favor the process of product promotion, since the MPR techniques suppose a cost infinitely lower than other marketing techniques such as traditional advertising in the media. From this point of view, the sponsorship of sporting events, art festivals, fairs and charitable annual events are becoming one of the most important parts in the lives of consumers allowing broadening and deepening the relationship of a company with its target market (ibídem, 2009: 739).

That is, contrary to the holistic perspective that is oriented towards the organizationpublic relationship, the marketinian perspective of public relations is oriented towards the relationship with the market, identifying the organization of events in a way to satisfy the needs of buyers and consumers. 


\section{Results and discussion}

In view of the above, it seems evident then that the fundamental difference between the holistic perspective and the marketing perspective is the root of the distinction between act and event. While the concept of act derives from the managerial, managerial conception, that of event is born from the hand of instrumentalized public relations as one of the P's of the marketing mix.

\subsection{The differences between act and event}

The bibliographic analysis made shows that the root of this division lies in the differential essence that separates both relational conceptions. The nature of managerial public relations, derived from the communicational and / or relational perspective of public relations, is oriented towards managing the relationships that an organization (business corporation, official institution, etc.) maintains with its public map through the establishment of a bidirectional communication system that allows to fluidify the transmission of pertinent institutional or corporate messages previously planned from strategic postulates. On the contrary, the concept of an event directly alludes to a marketing conception of public relations where one can no longer speak of the establishment of a communication system of one's own, but subjugated to the economic objectives of marketing (and, where appropriate, always a unidirectional), but in which public relations are used as a tool to serve the satisfaction of the economic needs of the company in its specific market.

This fact also justifies a non-exclusive relationship between both terminological categories since, from the academic and professional praxis, a symbiotic and constant interrelation between both relational perspectives is observable since, although from the managerial postulates it is possible to use, punctually, the events to improve the image of companies and institutions, is no less certain that for the organization of certain events the syntactic norms that suppose the ceremonial and the protocol for the organization of acts are necessary.

Under this prism, it is feasible to specify a series of key differences that derive from these perspectives, as can be seen in table 1 . 
Table 1. Strategic differences between act and event

\begin{tabular}{|c|c|c|}
\hline Sender & Act & Event \\
\hline Referent & $\begin{array}{c}\text { State } \\
\text { Companies } \\
\text { Other public and } \\
\text { private organizations }\end{array}$ & $\begin{array}{c}\text { Companies } \\
\text { Non-profit organizations }\end{array}$ \\
\hline Message & Sender & $\begin{array}{c}\text { Products } \\
\text { Brands }\end{array}$ \\
\hline Porpouse & $\begin{array}{c}\text { Solemnity } \\
\text { Legitimization }\end{array}$ & $\begin{array}{c}\text { Brands or products } \\
\text { distinctive characteristics }\end{array}$ \\
\hline Receiver & Image & $\begin{array}{c}\text { Sale } \\
\text { Reputation }\end{array}$ \\
\hline Communication & $\begin{array}{c}\text { Map of publics } \\
\text { Stakeholders }\end{array}$ & Target \\
\hline system & $\begin{array}{c}\text { Autonomous } \\
\text { Bidirectional }\end{array}$ & $\begin{array}{c}\text { Subjugated to the MK } \\
\text { objectives } \\
\text { Unidirectional }\end{array}$ \\
\hline $\begin{array}{c}\text { Some traditionals } \\
\text { forms }\end{array}$ & Inaugurations \\
Commemorations & $\begin{array}{c}\text { Product tastings } \\
\text { Sports competitions } \\
\text { Awards }\end{array}$ & Concerts \\
\hline
\end{tabular}

From: Own elaboration

Based on these classifications, it is possible to determine a series of specific tools through which the different types of acts and events tend to materialize.

\subsection{Managerial tools for the organization of acts}

Among the typical tools most commonly used in the organization of acts as a public relations technique with a purpose, therefore, corporate or institutional are the following:

- Press conferences and other meetings with the media

- Inaugurations of buildings, offices or services

- First stone placement

- Visits to works

- Institutional visits

- Commemorations and ephemeris

- Coronations and promulgations

- Signing of agreements

- Meetings and visits

- Institutional lunches and dinners 
- Award ceremonies

- Official or corporate receptions

- Congresses, seminars and symposia

- Etc.

\subsection{Management tools for the organizations of events} Among the typical tools most commonly used in the organization of events as a promotion technique with a purpose derived, therefore, from its instrumentalization in the marketing process, are the following:

- Brand or product presentations

- Participation in fairs

- Commercial conventions

- Products tastings

- Parades

- Promotions

- Brand or product parties

- Brand or product concerts

- Brand or product festivals

- Brand or product exhibitions

- Concerts

- Cultural festivals

- Exhibitions

- Gamer events

- Competitions

- Performances and shows

- Etc. 


\section{Conclusions}

The organization of events and events is one of the essential areas of communication management of companies and institutions. The key issue is that while the organization of events can be identified with the relational management of corporate and institutional communication, the organization of events is directly related to the achievement of the economic objectives of the company and therefore, to commercial communication.

Consequently, this analysis shows that, what a priori could have been understood as a simple question of synonymy, actually reveals a genuine conceptual abyss related to the purpose of the corporate or institutional use that is provided to the organization of events or events at this point it is evident that:

- There are inherent key differences, which define, identify and differentiate each of the terms from each other,

- It is possible to identify techniques or management tools specific to each of the conceptual categories analyzed.

Under these premises, we can therefore conclude that the organization of events is a genuine technique of commercial communication, inserted in the marketing process, as one of the controllable variables, in the P for the promotion of the Marketing Mix.

\section{Bibliography}

Armstrong, G \& Kotler, P. (2016). Marketing. Introduccion. Madrid: Pearson.

Austin, E. W. \& Pinkleton, B. E. (2015). Strategic Public Relations Management: Planning and Managing Effective Communication Programs. New York: Taylor \& Francis.

Castillo, A. \& Fernández, M. J. (2015). Protocolo y relaciones públicas. Madrid: Síntesis.

Castillo, A. (2010). Introducción a las relaciones públicas. Málaga: IIRP.

Grunig, J. E. \& Hunt, T. (2000). Dirección de relaciones públicas. Barcelona: Gestión 2000.

Kotler, Keller, Brady, Goodman y Hansen (2009) Marketing Management. Pearson Education Limited Harlow, England.

Kotler, P Y Keller, L. (2006). Dirección de Marketing. Madrid: Pearson Prentice Hall. 
Ledingham, J. A. \& Bruning, S. D. (1998). Relationship management in public relations: dimensions of an organization-public relationship, en Public Relations Review, 24 (1), pp. 123-137.

Ledingham, J. A. (2003). Explicating Relationship Management as a General Theory of Public Relations, en Journal of public relations research, 15 (2), pp. 234-257.

Ledingham, J. A. (2006). "Relationship management: a general theory of public relations". In: L'Etang, J. \& Pieczka, M. (2006). Public Relations. Critical debates and contemporary practice. Mahwah (New Jersey): Lawrence EarlbaumAssociates, Inc.

Otero, M. T. (2009). Protocolo y organización de eventos. Barcelona: Ed. UOC.

Otero, M. T. (2011). Protocolo y empresa. El ceremonial corporativo. Barcelona: Ed. UOC.

Otero, M. T. (2017). ¿Cómo se organizan los actos corporativos? Barcelona: Ed. UOC.

Philip J. Kitchen, Ioanna C. Papasolomou, (1997) "Marketing public relations: conceptual legitimacy or window dressing?", Marketing Intelligence \& Planning, Vol. 15 Issue: 2, pp.71-84, https://doi.org/10.1108/02634509710165876

Pulido, M. (2012). Técnicas de relaciones públicas en la comunicación organizacional, en Revista Internacional de Relaciones Públicas, 3, pp. 84-97.

Pulido, M. (2015). Ceremonial y Protocolo: métodos y técnicas de investigación científica, en Opción, 1, pp. 1457-1468.

Pulido, M. (2016). Manual de organización de actos oficiales y empresariales. Madrid: Editorial Síntesis.

Ramos, F. (2008). El protocolo de empresa: herramientas para crear valor. A Coruña: Netlibro.

Reinares, P. Y Paredes, M. (2003). "Relaciones Públicas". En: Bigné, E. (Coord.) Promoción comercial. Madrid: ESIC.

Sánchez, M. D. M. (2011). Fundamentos del ceremonial y el protocolo. Editorial Síntesis: Madrid.

Sánchez, M. D. M. (2016). Técnicas de organización de eventos. Madrid: Editorial Síntesis.

Sánchez, M. D. M., Gómez Requejo, M. V. \& Pérez Margos, R. M. (2015). Historia del ceremonial y del protocolo. Madrid: Editorial Síntesis.

Seitel, F. (2002). Teoría y práctica de las relaciones públicas. Madrid: Prentice Hall.

Wilcox, D. L., Autt, P. H., Agee, W. K., \& Cameron, G.T. (2000). Relaciones públicas. Estrategias y tácticas. Madrid: Pearson Addison Wesley.

Wilcox, D. L., Cameron, G. T. \& Xifra, J. (2009). Relaciones públicas. Estrategias y tácticas. Madrid: Pearson Addison Wesley. 
Wilcox, D. L., Cameron, G. T. \& Xifra, J. (2012). Relaciones Públicas: Estrategias y tácticas. Madrid: Pearson.

Xifra, J. (2003). Teoría y estructura de las relaciones públicas. Madrid: Mc Graw Hill.

Xifra, J. (2005). Planificación estratégica de relaciones públicas. Barcelona: Paidós.

Xifra, J. (2007). Técnicas de las Relaciones Públicas. Barcelona: Editorial UOC.

Xifra, J. (2010). Relaciones públicas, empresa y sociedad. Barcelona: UOC.

Xifra, J. (2011). Manual de relaciones públicas e institucionales. Madrid: Tecnos. 